\title{
OBITUARY
}

\section{Feodor Lynen, 1911-1979}

FEOdor LyNEN died in Munich on 6 August 1979, of complications following surgery to repair an aneurysm in his aorta. It was quite typical of the man that, while in hospital preparing for surgery, he arranged that former colleagues and friends attending the Acta Endocrinologica Congress in Munich last June should receive, personally, messages of regret that he would be unable to meet them. With his death, we have lost a great biochemist, and many, the world over, have lost a good friend.

Fitzi Lynen was a Bavarian, and pround of it. He was born in Munich in 1911; he went to school and university there and then he worked there. So great was his fame, he must have had many attractive offers from other centres of learning, but his love for Bavaria kept him in Munich. $\mathrm{He}$ travelled widely, however, and made innumerable lasting friendships wherever he went.

At an early stage in his career, he came under the influence of the great German chemist, Heinrich Wieland. This training and the chemical skills which he developed, and encouraged in his laboratory associates, are clearly seen in all his work. He graduated PhD in 1937, became Dozent in 1942, Professor of Biochemistry in 1953, and shortly afterwards became Director of the Max-Planck Institute for Cell Chemistry. Later, he was to become VicePresident of the Max-Planck Society, President of the Alexander von Humbolt Foundation, and President of the International Union of Biophysics. At the time of his death, he was President of the International Union of Biochemistry.

Lynen's researches aimed to elucidate the chemical details of metabolic processes, and the mechanisms of their regulation. His first brilliant observation came in 1951, when he reported in Angewandte Chemie that acetyl-coenzyme A is "active acetate". This was something of a surprise, since at the time it was popularly believed that "active acetate" would prove to be a phosphate. However, Lynen's keen chemical insight led him to appreciate that sulphydryl groups are acidic and that thio esters would behave like anhydrides and thus as acetylating agents.

Considering the range of topics covered by Lynen's publications, one cannot fail to be impressed by his achievements. The Pasteur effect, acetic acid degradation in yeast, the isoprene unit, biotin and the fixation of $\mathrm{CO}_{2}$, cythohaemin, the biosynthesis of cysteine, terpenes, cholesterol and fatty acids and many

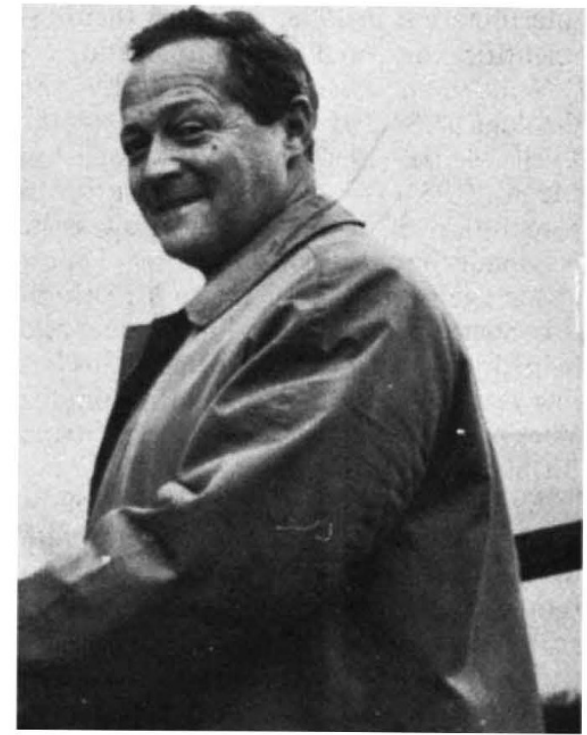

others, were dealt with in papers making giant strides in the advancement of knowledge.

In recognition of this magnificient work, Lynen was honoured by universities in Europe, America and Asia. In 1964, he was awarded a Nobel Prize in Physiology and Medicine, jointly with Konrad Bloch.

Despite the honours heaped upon him Lynen remained an approachable, jovial, friendly man. Students loved him, as was abundantly evident from their contributions to his 65 th birthday party, an affair which was very Bavarian and far from solemn and dignified. Working in Lynen's Laboratory was an unforgettable experience. At times, he could be a strict disciplinarian, expecting long hours of work and the meeting of deadlines, but this was always tempered by good humour and no one worked harder than Fitzi. One could not fail to be enthusiastic when he was about. Difficulties were made to be overcome, and quickly. Vast quantities of mitochondria appeared overnight, a press for breaking yeast cells was made in a day or two. It was unthinkable to leave the Laboratory before Fitzi had completed his round. Then, as the slightest excuse, or none at all, everyone, Fitzi included, would finish the day in some popular "Local", drinking beer and eating sausages. Of course, work started as usual at eight the next morning.

In 1937, Lynen married Eva Wieland, and they had five children. Frau Lynen was greatly concerned about the welfare of those who worked with her husband, and visitors to the laboratory were welcomed with charming and generous hospitality at the Lynen home in Starnberg. Much of the conversation would be about music and skiing. The number of times Fitzi had broken a leg at the latter activity was legend.

We remember Fitzi Lynen the brilliant scientist, and find it difficult to forget the jovial, limping figure, with the mischievous grin, attiring himself in his office curtains to lead the biochemists at some Faschingsparty.

\section{J. K. Grant}

\section{J. Wills}

LONGEVITY is not unusual in geologists, but it is rare in any branch of science to record the passing of one who continued to produce highly original and outstanding work well into his nineties, whose publications span more than seventy years, some of the later ones being among the most valuable.

Leonard Johnston Wills, Sc.D., Emeritus Professor of Birmingham University, who died on 12 December 1979, shortly before his 96th birthday, graduated with a double first at King's College, Cambridge. He was awarded the Harkness Scholarship and Walsingham Medal and a Fellowship at King's College. After four years with the Geological Survey, mapping in the Llangollen area of North Wales, he took in 1913 a Senior Lectureship at Birmingham University, and succeeded to the Chair of Geology in 1932, continuing there until his retirement in 1949.

Wills' first paper (1907) described the discovery of fossils in the generally barren Keuper rocks of the Birmingham area. This led him in later years to an interest in the fauna of other continental formations, and to extensive studies of fossil scorpions and eurypterids for which he developed ingenious original methods of dissection, revealing detailed anatomical details including the respiratory and reproductive organs.

His concern with the Trias lay also in environmental aspects - a continuing thread in his work - and in the vexed problems of stratigraphic correlation which led to one of his final papers (1976) which described the Trias of the West Midlands in terms of sedimentary rhythmic units. The volume of new information in this work justified its publication by the I.G.S., but the rhythmic units are mostly of local extent. The regional problems are now being resolved by the new science of palynology. 
A further realm in which Wills made major contributions was in the Pleistocene history of the Midlands, with its story of advance and retreat of continental glaciers, recognising the evidence of extensive icedammed lakes of which one, which he named Lake Lapworth, covered much of the northwest Midlands. This was classic work which has served as the basis for all subsequent studies of Midlands glaciation and river development.

Wills' long term interest in the Palaeozoic rocks of Wales, in the contrasting regimes represented by the Midlands Trias blanketing concealed coalfields, in the marine later Mesozoic and in the complex deposits of the glacial period led to a series of books in which environmental aspects are a major theme. The first was his Physiographical Evolution of Great Britain (1929), later came The Palaeogeography of the Midlands (1948), A Palaeogeographical Atlas of the British Isles (1951), and Concealed Coalfields (1956).

Of these publications, the Palaeogeographical Atlas has been widely used by industry as well as by academics, being particularly valuable to the petroleum industry when North Sea exploration led to the requirement for broad regional appraisals. This made "Wills" a household name for petroleum geologists. It was a notable production, including 49 maps of Britain and the adjoining areas from the Lower Palaeozoic to the Quaternary, covering tectonics, palaeogeography, sedimentary facies and glaciation. Authorities are listed for each map - often ten or eleven individuals as well as the Geological Survey - demonstrating the thoroughness of the compilation. Many of the sources provided previously unpublished information, for example from the deep boreholes made in the course of onshore exploration for oil in the 1930s and 1940s.

Wills retired from the Chair of Geology in 1949 , but his thirty years in retirement were highly productive. After the work on the anatomy of fossil arthropods and publication of his text books he continued to work on problems of the Midlands Trias and to compile data on the deep geology of England and Wales. Increasing infirmity confined him to his country home near Romsley, but he was an indefatigable correspondent and kept in touch with a range of friends who could provide a flow of new information for analysis and compilation. At the age of 89 , in 1973 , he completed and published a palaeogeological map of the buried pre-Permian formations of England and Wales, a map which found an immediate place on the walls of many offices and most geological departments in the country.

It was assumed that in the face of physical frailty, with only one eye useable and a serious heart condition, this would be his last production, but two years later he followed this masterpiece with a palaeo- geological map at a deeper level - the surface of the strata with Upper Devonian and later formations removed, and this led in turn to a third map of pre-Devonian formations. Each map of this series threw new light on the deep structure and stratigraphic relations of deeply buried rocks. The last two were published together with a memoir on the data and on their interpretation in 1978, and with them his scientific work finally came to an end.

Wills had been honoured by the Geological Society by the award of the Lyell Medal (1936) and the Wollaston Medal (1954) - its highest award. In recognition of his continuing prowess he was made the only British Honorary Fellow at the age of 92. The Petroleum Exploration Society elected him a life member and helped to finance his maps, and in his last few years he received medals also from the Yorkshire Geological Society and from Birmingham University.

As a lecturer Wills was difficult to follow but inspired a generation of students with his enthusiasm and interest. In his retirement he could not have accomplished so much without the support of his old university, of a wide range of correspondents, and the devotion of his daughter who looked after him for nearly thirty years after the loss of his wife. But he attracted universal affection and cooperation, and his friends felt it a pleasure and honour to be able to help him in his continuing scientific achievement.

Peter Kent

\section{John W. Mauchly}

THE DEATH occurred on 8 January 1980 at the age of 72 of John W. Mauchly who, with Dr J. P. Eckert, conceived and carried through the project for the development of the first large-scale electronic computer. This was the ENIAC (Electronic Numerical Integrator and Computer), built at the Moore School of Electrical Engineering in Philadelphia during the latter part of the war.

Mauchly was born in Cincinnati in 1907 and grew up in Chevy Chase, Maryland. After taking his $\mathrm{PhD}$ at Johns Hopkins University, he went to Ursinus College as head of the physics department. During several summers he worked at the department of terrestrial magnetism of the Carnegie Institution in Washington DC, where his father was employed as a physicist. In this way, Mauchly acquired an interest in weather problems that he retained throughout his life. It was while he was working on a project for the analysis of weather records that he began to appreciate the pressing need for some automatic means of computation. He early realised the role that electronics might play and he began to do some experiments in his spare time.

In 1941 Mauchly joined the faculty of the University of Pennsylvania at the Moore School and there he met J. P. Eckert. Together, in 1942, they wrote the proposal for the ENIAC. They were able to interest the US Ordnance Department - which was facing an unprecedented wartime demand for the computation of ballistic tables - in the proposal, and as a result substantial funds were made available. The ENIAC was running by the summer of 1945 and was formally dedicated on 15 February 1946.

The ENIAC contained nearly 19,000 vacuum tubes and its construction represented an outstanding example of technological courage, both on the part of its young designers and on the part of those who gave them support. Its completion was an important landmark in the development of digital computers; however, even more significant in the long term was the formulation, by Mauchly and Eckert, in association with the ENIAC group, of the principles on which modern stored program computers are constructed.

Towards the end of 1946 Mauchly left the Moore School to found, with Eckert, the Eckert-Mauchly Corporation, intended to exploit the new ideas. All went well, although the development of a stored program computer to meet commercial standards was proving a long drawn-out process, until 1950, when they suffered a severe blow by the loss of their sponsor in an air accident. This led directly to the Eckert-Mauchly Corporation being absorbed in Remington-Rand, but happily the name UNIVAC, which they gave to their computer, has survived.

Mauchly remained with RemingtonRand, which in due course, became merged with the Sperry Corporation, until 1959, when he formed a consulting company of his own. In his later years he became associated once more, on a consulting basis, with UNIVAC.

Mauchly was a member of the National Academy of Engineering and a Fellow of the IEEE. He was one of the founders of the Association for Computing Machinery and was its President during the years 1948-50. In 1966 he received the Harry Goode Memorial Award of the American Federation of Information Processing Societies. In addition, he received numerous other honours and awards.

Mauchly was twice married. His first wife, Mary, whom he married in 1930, was drowned in a tragic bathing accident in September 1946. In February 1948 he married Kay McNulty, who had worked as a programmer on the ENIAC. She survives him, along with two sons and five daughters. Mauchly was a man of great personal charm, with a gentle approach to people and affairs. His many friends will miss him greatly.

M. V. Wilkes 